\title{
SOEP
}

SOEPpapers

SOEPpapers
on Multidisciplinary Panel Data Research

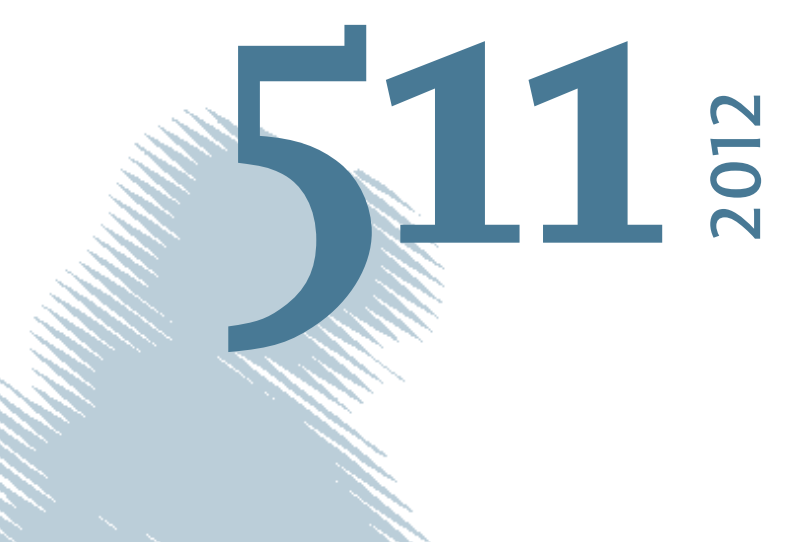

e

\section{Job Loss Fears and (Extremist) Party Identification: First Evidence from Panel Data}

Ingo Geishecker and Thomas Siedler 


\section{SOEPpapers on Multidisciplinary Panel Data Research}

at DIW Berlin

This series presents research findings based either directly on data from the German SocioEconomic Panel Study (SOEP) or using SOEP data as part of an internationally comparable data set (e.g. CNEF, ECHP, LIS, LWS, CHER/PACO). SOEP is a truly multidisciplinary household panel study covering a wide range of social and behavioral sciences: economics, sociology, psychology, survey methodology, econometrics and applied statistics, educational science, political science, public health, behavioral genetics, demography, geography, and sport science.

The decision to publish a submission in SOEPpapers is made by a board of editors chosen by the DIW Berlin to represent the wide range of disciplines covered by SOEP. There is no external referee process and papers are either accepted or rejected without revision. Papers appear in this series as works in progress and may also appear elsewhere. They often represent preliminary studies and are circulated to encourage discussion. Citation of such a paper should account for its provisional character. A revised version may be requested from the author directly.

Any opinions expressed in this series are those of the author(s) and not those of DIW Berlin. Research disseminated by DIW Berlin may include views on public policy issues, but the institute itself takes no institutional policy positions.

The SOEPpapers are available at

http://www.diw.de/soeppapers

\section{Editors:}

Jürgen Schupp (Sociology, Vice Dean DIW Graduate Center)

Gert G. Wagner (Social Sciences)

Conchita D'Ambrosio (Public Economics)

Denis Gerstorf (Psychology, DIW Research Director)

Elke Holst (Gender Studies, DIW Research Director)

Frauke Kreuter (Survey Methodology, DIW Research Professor)

Martin Kroh (Political Science and Survey Methodology)

Frieder R. Lang (Psychology, DIW Research Professor)

Henning Lohmann (Sociology, DIW Research Professor)

Jörg-Peter Schräpler (Survey Methodology, DIW Research Professor)

Thomas Siedler (Empirical Economics)

C. Katharina Spieß (Empirical Economics and Educational Science)

ISSN: 1864-6689 (online)

German Socio-Economic Panel Study (SOEP)

DIW Berlin

Mohrenstrasse 58

10117 Berlin, Germany

Contact: Uta Rahmann | soeppapers@diw.de 


\title{
Job Loss Fears and (Extremist) Party Identification: First Evidence from Panel Data
}

\author{
Ingo Geishecker
}

\author{
Thomas Siedler ${ }^{*}$
}

\author{
October, 2012
}

\begin{abstract}
There is a large body of literature analyzing the relationship between objective economic conditions and voting behavior, but there is very little evidence of how perceived economic insecurity impacts on political preferences. Using seventeen years of household panel data from the German Socio-Economic Panel, we examine whether job loss fears impact on individuals' party identification. Consistent with the deprivation theory, we find strong and robust evidence that subjective job loss fears foster affinity for parties at the far right-wing of the political spectrum. The effects are broadly comparable in direction and magnitude with the ones from objective unemployment and being out of the labor force. However, our empirical estimates do not suggest that job loss fears result in people withdrawing their support from political parties altogether or increasingly identify with extremist left-wing parties.
\end{abstract}

Keywords: Job insecurity, party identification, prospective voting, economic worries

JEL Classification: Jo1, J63, P16

\footnotetext{
${ }^{*}$ Geishecker: Georg-August University Göttingen, Department of Economics, Platz der Göttinger Sieben 3, 37073 Göttingen, Germany (E-mail: Ingo.Geishecker@wiwi.uni-goettingen.de); Siedler: University of Hamburg, Von-Melle-Park 5, 20146 Hamburg, Germany (E-mail: thomas.siedler@wiso.uni-hamburg.de) and Socio-Economic Panel Study(SOEP) at DIW Berlin, Mohrenstraße 58, 10117 Berlin, Germany. We gratefully acknowledge financial support from the Fritz Thyssen Stiftung and Deutsche Forschungsgemeinschaft, GE2074/1-2.
} 
"When you think economics, think elections; When you think elections, think economics"

Tufte, E. R. American Political Science Review, 1978

\section{Introduction}

Are people's political preferences influenced by their economic worries, and are individuals' job loss fears important for their pro-democracy attitudes? In particular, do job loss fears steer people away from the mainstream democratic parties and towards parties at the extremes of the political spectrum?

In the wake of what has now been labelled the Great Recession, in both the United States and Europe, people's job loss fears increased considerably. According to the Washington Post from September 2009, nearly sixty percent of Americans were concerned about job or pay losses (Cohen and Agiesta, 2009). On January 25, 2010 U.S. President Barack Obama used his State of the Union Address to reassure Americans worried about the economy and their job security: "We [...] need to reverse the overall erosion in middle-class security so that when this economy does come back, working Americans are free to pursue their dreams again". ${ }^{1}$ Similarly, many commentators in Europe voiced their concerns about people's feelings of economic insecurity. ${ }^{2}$

To date, there is scant evidence in the academic literature of potential political consequences of individuals' perceived economic insecurities in general, and of their job loss fears in particular. The economic and political science literature mainly focuses on the relationship between objective microeconomic and macroeconomic variables (e.g., income, education, unemployment, family structures, GDP, inflation, unemployment rates) and an individual's party identification,

\footnotetext{
${ }^{1}$ See, for example, http://www.reuters.com/article/idUSTRE60K03H20100125 for further information.

${ }^{2}$ See, for example, Meyer-Timpe (2010).
} 
political participation, and voting. ${ }^{3}$ First suggestive empirical evidence that people's economic worries might impact on economic and political outcomes comes from historical voting behavior research. Falter (1983) and King, Rosen, Tanner and Wagner (2008) examine how free democratic elections in the Weimar Republic resulted in electoral successes for the antidemocratic Nazi Party in Germany. Falter (1983) argues that it was mainly those Germans who feared the loss of their economic status that supported the Nazis, rather than the unemployed. In a similar vein, King and his co-authors conclude that professionals, self-employed shopkeepers, domestic workers and the family members assisting them, i.e., those who "feared that they would lose the independence that their self-owned businesses provided" (King et al., 2008: 961) - supported the Nazi party. Clearly, while the events of the Weimar Republic that resulted in the end of democracy and the rise of the Nazis cannot be compared directly with the political and economic circumstances of today's Germany, the empirical studies by Falter (1983) and King et al. (2008), nevertheless, point out that economic fears might indeed have important social, economic, and political consequences. Moreover, recent right-wing murders in Germany, Italy, and Norway underscore the problem of right-wing extremism in Europe. In December 2011, two African street vendors were murdered by a right-wing extremist in Florence. ${ }^{4}$ In Germany, the neo-Nazi terrorist cell National Socialist Underground (NSU) killed at least 10 people (New York Times, 2011). In the wake of these attacks, the German police arrested a former senior party official of the far right-wing National Democratic Party (NPD) in Thuringia who is suspected of assisting the NSU in six murders and one attempted murder.

The present paper is the first to study how self-reported job loss fears impact on party identifica-

\footnotetext{
${ }^{3}$ See, for example, the recent studies by Schneider (1984), Lewis-Beck (1986), Lewis-Beck (1988), Powell and Whitten (1993), Anderson (2000), Edlund and Pande (2002), Weisberg and Smith (1991), Brunner, Ross and Washington (2011), Alesina and Giuliano (forthcoming), Siedler (2010) and Oswald and Powdthavee (2010).

${ }^{4}$ See http://www.spiegel.de/international/europe/0,1518,803938,00.html.
} 
tion among employed people ${ }^{5}$, using rich individual-level longitudinal data. The previous economic voting literature has relied mainly on cross-sectional or aggregate time series data. ${ }^{6}$ Analysis of individual panel data offers the key advantages of enabling us to estimate causal effects by controlling for individual unobserved heterogeneity. Second, this study analyzes whether economic worries reduce people's propensity to feel close to mainstream democratic parties, and increases the risk of support for parties at the extreme left and particularly the extreme right of the political spectrum. In this respect our empirical analysis relates to recent theoretical contributions on the formation of nationalism and xenophobia (see e.g., Corneo, 2010, Corneo and Jeanne, 2009). Moreover, this paper examines how economic worries impact on whether citizens actually do not feel close to any political party. This is important because many western democracies experience a decline in party identification and associated voter turnout over time (see, for example, Abramson, 1976, Dalton, 2002).

This study exploits the longitudinal nature of the German Socio-Economic Panel Study (SOEP), which contains detailed questions about individuals' job loss fears and their party identification. The panel estimations suggest that job loss fears foster affinity for right-wing extremist parties. For the West German sample, the estimates accounting for unobserved time-constant personality traits suggest that individuals who are very concerned about their own job security have a 41 percent higher relative risk of expressing an affinity to a far right-wing party than those without job loss fears. In the East German sample, the effects are stronger in magnitude, suggesting that employees who are very concerned about their own job security have a 90 percent higher relative risk of identifying with right-wing extremist parties. Overall, these findings indicate that individual

\footnotetext{
${ }^{5}$ In line with the literature, the terms party identification, party support, party attachment, and leanings are used interchangeably.

${ }^{6}$ Notable exceptions are the studies by Weatherford (1978) who uses three waves $(1856,1958$, and 1960) of panel data from the SRC American panel survey and the recent studies by Brunner et al. (2011), ?.
} 
economic worries and job loss fears are important for people's political party identification.

\section{Related Literature}

Our paper is interdisciplinary in nature and contributes to the economic and political science literature. Previous studies with a similar approach include individual-level analyses of the economic voting literature examining associations between individuals' economic perceptions and their political preferences. Seminal work by Lewis-Beck (1988) examines the relationship between economic conditions and voting behavior in the United States and Western European democracies. Among many other important findings, his work suggests that if economic circumstances worsen, citizens are more likely to vote against the incumbent party (and vice versa), and that individuals' economic perceptions of the near future appear to be as important as their assessments of the recent past. Malhotra and Krosnick (2007) report a positive and statistically significant relationship between presidential vote choice and candidates' prospective performance assessments (on Iraq, the economy, and terrorism) in the 2004 U.S. election campaign. Similarly, Sheafer (2008) finds a positive significant correlation, in Israel, between individuals' perceived future economic performance of the incumbent party and whether or not they intend to vote for the Prime Minister's party.

Of relevance to our paper are also the various economic and psychological studies investigating the consequences of individuals' beliefs about their own job security. Blanchflower (1991) reports that fears of plant closures or redundancy are significantly related to lower pay. Stephens (2004) finds that workers' fears of job displacement predicted actual displacements later on. Recent studies by Nolan, Wichert and Burchell (2000), Wichert (2002) and Rätzel and Knabe (2009) report a strong negative relationship between higher levels of job loss fears and individual job satisfaction and overall life satisfaction. Campbell, Carruth, Dickerson and Green (2007) uses longitudinal data from the British Household Panel Survey (BHPS) to examine whether subjective expectations of 
unemployment are reliable predictors of the actual probability of becoming unemployed. The authors find that workers' perceptions of job insecurity contain useful private information and are good indicators of future unemployment, conditional on observed variables such as previous unemployment experience and type of job contract. Further, they also find that perceptions of job insecurity have substantive economic implications as they are significantly related to lower wage growth for men.

In line with the work of Campbell et al. (2007) and Rätzel and Knabe (2009), our longitudinal data have the advantage of providing repeated observations on individuals' expectations and job loss fears over time, and they can be linked to individuals' own economic histories and to future events such as subsequent labor market experiences and party identification. Unlike Campbell et al. (2007), whose analysis is confined to measures of unemployment expectations in two waves of the BHPS only, we are able to observe respondents' job loss fears and party identification over nearly two decades.

\section{$3 \quad$ Theory and Hypothesis}

Our empirical work is inspired by Downs (1957) and his rational voter model. The standard economic voting model assumes that individuals make electoral decisions based on their perceptions about the state of the economy. The economic voter hypothesis suggests that voters support the current administration if the economy is doing well: otherwise, they vote against it. Downs also assigns an important role to individuals' future expectations, arguing that voters not only respond to the past and present national economic performance but also to the economic future. An extensive empirical literature has discussed whether economic voters are retrospective or prospective, with very mixed results to date. ${ }^{7}$ The majority of prospective economic studies measure respondents'

\footnotetext{
${ }^{7}$ For a recent survey of the literature see Lewis-Beck and Stegmaier (2000).
} 
expectations regarding the national economy, rather than using individuals' own expected economic circumstances, their subjective economic worries or job loss fears. Moreover, our study also relates to the relative deprivation theory (Falter, 1994), suggesting that the fear or experience of unemployment triggers feelings of deprivation, resulting in a higher risk of developing anti-foreign sentiments, preferences for authoritarian leaders, and affinities to extremist right-wing parties.

Several studies point out that economic voting might be muted in fractionalized party systems, in the presence of multi-party governments, or if opposition parties have a strong influence on political decisions (Anderson, 2000). This might be the case in Germany. Since World War II, the country has mainly be ruled by coalition governments. Further, Bundesländer (federal state) governments often differ from the ruling coalition's position at the national level, which regularly results in opposing political majorities in the lower and the upper houses of parliament. Hence, it might be rather difficult for German citizens to assign credit and blame for economic policies and the state of the economy to a particular party, as political power is often shared among several major parties and also influenced by opposition parties.

The present study, therefore, deviates from the standard economic voting literature and investigates the hypothesis that individuals withdraw their support for the mainstream parties and tend instead towards having no party identification or towards supporting parties at the extremes of the political spectrum.

Workers with high job loss fears might express their feelings of resentment towards the mainstream democratic parties by supporting political parties that openly criticize economic modernization and globalization. In Germany, extremist right-wing parties and the far left-wing party (Die Linke) take a rather protectionist and anti-capitalist stance. For example, a statement from the extremist National Democratic Party (NPD) from March 3, 2010, claims: "We create work by protecting the domestic economy from cheap foreign products. Globalization is flooding our 
markets with textiles and toys, information technology, consumer electronics, and car parts from low-wage countries. On a superficial level, free trade means cheaper goods, but the resulting decline in domestic industrial sectors creates unemployment and reduces purchasing power." Related to this anti-capitalist rhetoric are the promises made by both the far left and the far right to protect the jobs and employment opportunities of the working class. Moreover, these parties sell themselves as distinguishable alternatives to the mainstream parties. The preamble from a recent draft by the programme commission of Die Linke published on March 20, 2010 begins with the statement: "Die Linke stands for alternatives, for a better future. We are not and will not be like those parties which devoutly submit to the wishes of the powers of the economy and precisely therefore are hardly distinguishable from one another" (Die Linke, 2010). Note that no party identification can also indirectly give weight to parties at the extremes of the political spectrum as it seems likely that the absence of any party identification also reduces the propensity to vote.

\section{Data}

This study uses annual household panel data from the German Socio-Economic Panel Study (SOEP). The SOEP is a representative longitudinal sample of the German population living in private households. The first wave of the SOEP was conducted in 1984 surveying persons living in private households in the Federal Republic of Germany. In 1990, shortly after German reunification, the survey was extended to the former German Democratic Republic. The SOEP collects repeated information on demographics, labor market outcomes, education, housing, health and political attitudes over time. It is similar to the Panel Study of Income Dynamics (PSID) in the United States and the British Household Panel Study (BHPS) in the United Kingdom. For further information about the SOEP, see Haisken-DeNew and Frick (2005) and Wagner, Frick and Schupp (2007). 
A key advantage of the SOEP is that it provides a representative sample of the working population over a relatively long time period. We use the panel years 1993 to 2009, as these are the waves in which respondents' party identification is surveyed, including party identification for parties at the extremes of the political spectrum. We restrict the sample to individuals with German nationality who are aged 18 to 60 at the time of the interview. Certain types of civil servants (Beamte) are excluded from the analysis because the likelihood of them losing their jobs is approximately zero. Previous work reports considerable differences in preferences for redistribution and trust in legal institutions and political authorities between East and West Germans (Alesina and FuchsSchndeln, 2007, Rainer and Siedler, 2009). Similar to these studies, we define a person as being from the East if he or she lived in East Germany before reunification, irrespective of the current place of residence. ${ }^{8}$ Overall, our West German sample consists of roughly 105,000 person-year observations for 14,860 individuals of which about 11500 are currently employed. The East German sample comprises around 50,700 observations, with 6,501 individuals of which about 5100 are currently employed. For replication purposes the data and associated program files can be made available on publication through the SOEP "Archive for Re-Analysis of Published Findings".

\subsection{Political Party Identification}

Our outcome measures for political party identification are derived from answers to the following question: "Many people in Germany are inclined towards a certain political party, although from time to time they vote for a different party. What about you: Are you inclined-generally speaking - toward a particular party?" Those who respond 'yes' are then asked to state the party toward which they are inclined. ${ }^{9}$

\footnotetext{
${ }^{8}$ Respondents who are born in East Germany after the collapse of the Berlin Wall are also defined as being from the East.

${ }^{9}$ Party identification therefore refers to an affective attachment of individuals to a particular party. Recent research on political party identification based on the SOEP include Kroh and Selb (2009a, b), Zuckerman, Dasovic
} 
Our outcome variable distinguishes between four mutually exclusive categories. The first category - Mainstream party identification — comprises individuals who answer that they are inclined towards one of the four major German parties, the Christian Democrats (CDU/CSU), the Social Democrats (SPD), the Free Democratic Party (FDP) or the Greens (Alliance90/The Greens). The second category — No party identification — includes those who respond that they are not inclined towards a particular party. One of the main reasons for studying the absence of party identification is that an increasing share of the adult German population reports having no party identification. For example, 65 percent of West Germans reported a party affinity in 1984, compared to 43 percent in 2009. A similar declining trend can be observed in voter participation. According to official statistics, 88.4 percent of the electorate cast a vote in the German general election in 1983. In the 2009 general election, voter turnout was only 70.8 percent (Bundeswahlleiter, 2009). ${ }^{10}$

The third category — Far left-wing party identification — includes those individuals who answer that they are inclined towards the far left-wing (post-communist) Party of Democratic Socialism (PDS) and its spinoff Die Linke. ${ }^{11}$. Die Linke was formed in June 2007 from a merger of the West German Party of Labour and Social Justice (WASG) and the PDS. Since then, the party has recorded electoral successes, not only in East Germany, but also in western federal state elections. Neu (2004), in a comprehensive study on the PDS, examines the party's understanding of democracy, its ideology, and its extremist tendencies. The author argues that the post-communist party, PDS, can be regarded as being at odds with the German constitution in several respects. However, she also concludes that, in East Germany, the PDS can be regarded as a 'normal' party that competes with all the other mainstream parties (Neu, 2004: 254).

and Fitzgerald (2007) and Siedler (2011).

\footnotetext{
${ }^{10}$ The turnout rate in West Germany (including West Berlin) was 72.2 percent, and in East Germany (including East Berlin) 64.7 percent.

${ }^{11}$ The PDS was the successor party to the Socialist Unity Party (SED), the communist party that ruled the German Democratic Republic from 1949 until the elections of March 1990.
} 
The fourth category of the outcome variable — Far right-wing party identification — includes respondents who support one of the three extremist right-wing (neo-fascist) parties National Democratic Party (NPD), German People's Union (DVU), or The Republicans (Die Republikaner). With electoral successes of far right-wing parties in Austria, France, Italy, the Netherlands, and Germany in recent years, few people dispute their relevance and potential dangers. In addition, in November 2011, the German police arrested a former senior party official of the NPD in Thuringia who is suspected of assisting in six murders and one attempted murder committed by the neo-Nazi cell Nationalist Socialist Underground. Recent studies on far right-wing parties in Europe include, for example, Arzheimer (2008) and Oesch (2008). Westle and Niedermayer (1992), Lubbers and Scheepers (2000), and Siedler (2011) draw special attention to right-wing extremist parties in Germany.

It is important to point out that our outcome measures of party identification are aimed at measuring an enduring attachment to a political party that is likely to be distinct from current political preferences (see, for example, Campbell et al., 1960, Brynin and Sanders, 1993, and Bartle, 2003). As such, our study draws upon the work of Downs (1957) who argues that individuals are motivated by economic and social considerations and that party identification can be seen as a 'rational habit'. Thus, party identification can be revised if individuals think that a particular political party no longer acts in accordance with their own interests and values. ${ }^{12}$

Table 1 displays the proportion of individuals with a mainstream party identification, no party identification, with a far left-wing and those with a far right-wing party identification, for the years 1993 and 2009. The upper panel in Table 1 shows that the overwhelming majority of West Germans who express a party identification display an affinity towards one of the the four

\footnotetext{
${ }^{12}$ Fiorina (1981) also argues that party identification can adapt quickly to economic and political events. For a detailed overview of and discussion about the various interpretations of party identification in the political science literature see Bartle (2003).
} 
mainstream parties. However, the strength of support for these parties declined over time, from 42 percent in 1993 to 37 percent for the year 2009. In contrast, support for the far left-wing party Die Linke increased from a very low level in 1993 to 1 percent by the end of the observation period. Party identification for the extremist right fluctuates between 0.6 and 1.5 percent. It is also striking that, over time, an increasing proportion of the West German population does not identify with a political party. Over the seventeen years covered by the study, the proportion of West Germans with no party identification increased from 55 percent to around 60 percent.

The lower panel in Table 1 displays the evolution of party identification among East Germans. The first thing to note is that the proportion of East Germans with a mainstream party identification is much lower than among West Germans, and the proportion with no party identification is considerably higher. Fewer than one in three East Germans support the CDU/CSU, SPD, FDP or the Greens, and more than 70 percent report no party identification in both years. Similar to how the situation developed in West Germany, support for the mainstream parties decreased over time. In addition, support for the former socialist party, Die Linke, increased considerably from around 3 percent in 1993 to around 6 percent in 2009 . 
Table 1: Party Identification, 1993 and 2009 in percent

\begin{tabular}{|c|c|c|c|c|c|}
\hline Year & $\begin{array}{l}\text { Mainstream } \\
\text { party }\end{array}$ & $\begin{array}{l}\text { Extremist left- } \\
\text { wing party }\end{array}$ & $\begin{array}{l}\text { Extremist right- } \\
\text { wing party }\end{array}$ & $\begin{array}{l}\text { Other small } \\
\text { parties }\end{array}$ & $\begin{array}{c}\text { No party } \\
\text { identification }\end{array}$ \\
\hline
\end{tabular}

Panel A: West Germans

1993

42.05

0.05

1.53

0.50

54.80

2009

37.31

1.03

0.60

0.50

59.74

Panel B: East Germans

1993

22.80

2.87

1.10

0.32

72.09

2009

19.32

6.17

1.14

0.46

72.33

Notes: Main party identification is defined as being inclined towards one of the four major German parties, the Christian-Democrats (CDU/CSU), the Social Democrats (SPD), the Free Democratic Party (FDP) or the Greens (Alliance90/The Greens). The variable - No party identification - equals one if a person says that he/she does not feel close to any particular party. Extremist left-wing party is defined as feeling close to the party Die Linke, and extremist right-wing party affinity is defined as feeling close to one of three extremisrt right-wing parties in Germany. SOEP, wave 1993 and 2009. 


\subsection{Job Loss Fears}

In each annual wave, the SOEP also elicits respondents' beliefs about their own job security. The question reads: "What is your attitude towards the following areas — are you concerned about them?". Among the items listed is. "If you are employed: your job security". Respondents can answer on a three-point scale, indicating whether they are "very concerned", "somewhat concerned" or "not concerned at all". Based on these answers, we generate three mutually exclusive dummy variables.

Figure 1 illustrates the development of West Germans' feelings of job security between 1993 and 2009. The period saw the proportion of West Germans who are not concerned about their job security decrease from 60 percent to nearly 40 percent. The period also witnessed an increase in the proportion of West German workers who are very concerned about their job security from around 8 to 15 percent. Similarly, 40 percent of West Germans in 2009 express being somewhat concerned about their job security, compared to 31 percent in 1993.

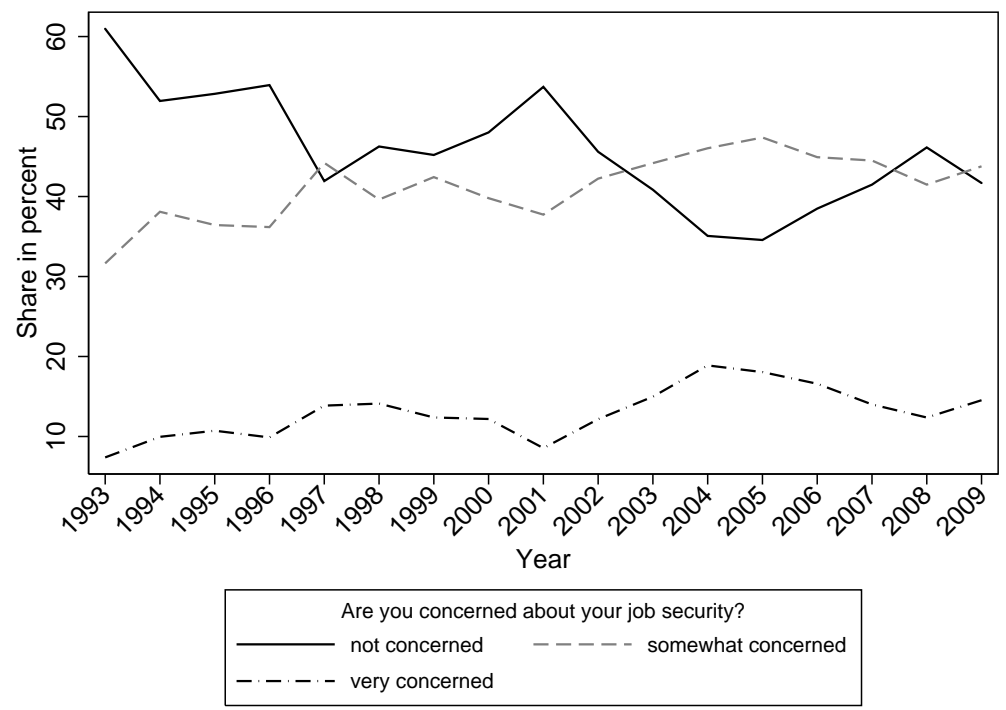

Figure 1: Development of Job Loss Fears, West Germans

Figure 2 shows that job loss fears are more prevalent among East German workers. For instance, 
around 50 percent of East Germans express being somewhat concerned about their job security. The proportion increased from 43 percent in 1993 to 50 percent in 2000, and remained stable thereafter. Similarly, high job loss fears are also more prevalent among East Germans, with around 20-30 percent saying that they are very concerned about their job security, compared to 8-20 percent among West German employees.

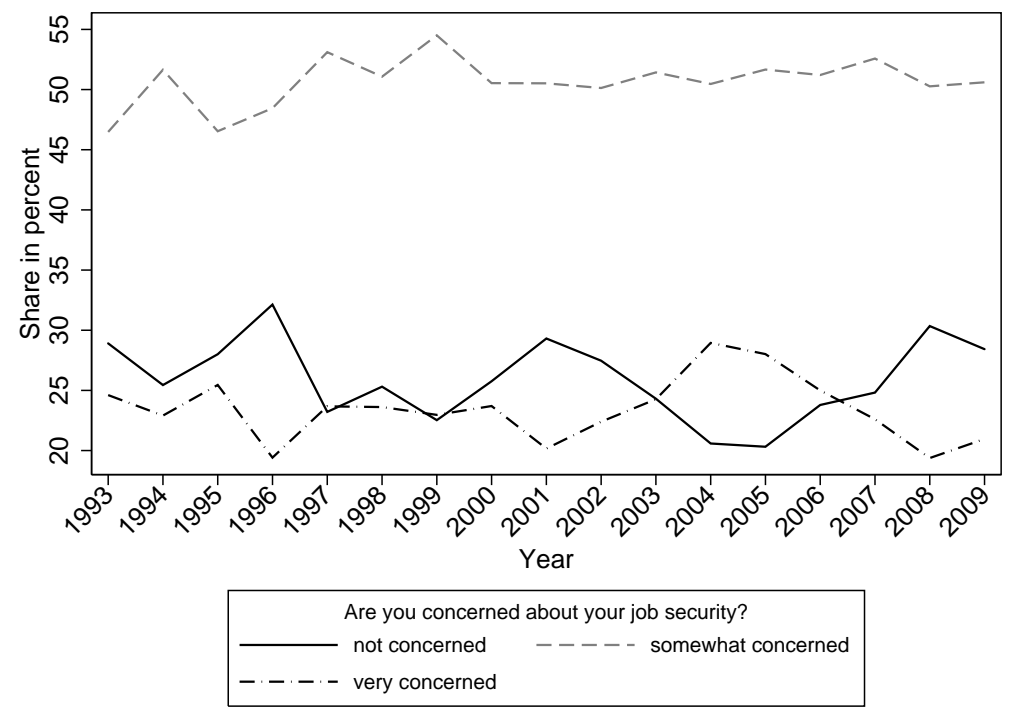

Figure 2: Development of Job Loss Fears, East Germans

\subsection{Dynamics of Party Identification and Job Loss Fears}

To understand the magnitude of changes in people's party identification and their job loss fears, we start by investigating transition matrices. Table 2 displays how individuals' party identification varies over time, using rolling one-year changes over the period 1993-2009. The upper panel in Table 2 shows that there is substantial change in West Germans' party identification. For example, 22 percent of West Germans who reported affinity toward a mainstream party in one year (t-1) report having no party identification in the next year (t). However, fewer than 1 percent who reported affinity to a mainstream party in the previous year indicate being close to either the far left-wing party or an extremist right-wing party in year t. Table 2 also shows that 77 percent of 
West German respondents do not change their mainstream party identification between any two survey years. The persistence in mainstream party identification is, therefore, considerably higher than than that with the far left-wing party (47 percent) and far right-wing parties (45 percent). The highest degree of persistence can be found among those who do not feel close to any particular party: 81 percent of West Germans who expressed no party identification in one year also report none in the following year. With regard to outflows from the extremes of the political spectrum, 19 percent of West Germans who reported a far left-wing party identification in year $t-1$ indicate being close to a mainstream party in year $\mathrm{t}$, and 32 percent of them report no party identification. The corresponding figures for those who report an extremist right-wing party identification in the previous year are 13 percent and 38 percent, respectively.

Table 2: Transitions in Party Identification

\begin{tabular}{|c|c|c|c|c|}
\hline & $\begin{array}{c}\text { Mainstream } \\
\text { party }_{t}\end{array}$ & $\begin{array}{c}\text { Extremist left- } \\
\text { wing party }\end{array}$ & $\begin{array}{c}\text { Extremist right- } \\
\text { wing party } t\end{array}$ & $\begin{array}{c}\text { No party } \\
\text { identification }\end{array}$ \\
\hline \multicolumn{5}{|l|}{ Panel A: West Germans } \\
\hline Mainstream party $_{t-1}$ & 76.80 & 0.28 & 0.19 & 21.86 \\
\hline Extremist left-wing party ${ }_{t-1}$ & 18.80 & 47.00 & 0.78 & 32.11 \\
\hline Extremist right-wing party ${ }_{t-1}$ & 12.54 & 0.88 & 45.41 & 37.81 \\
\hline No party identification $_{t-1}$ & 17.65 & 0.29 & 0.35 & 80.65 \\
\hline \multicolumn{5}{|l|}{ Panel B: East Germans } \\
\hline 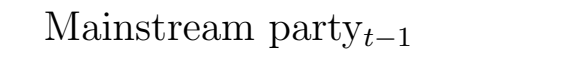 & 67.23 & 1.77 & 0.43 & 29.87 \\
\hline Extremist left-wing party ${ }_{t-1}$ & 6.72 & 66.30 & 0.52 & 25.64 \\
\hline Extremist right-wing party ${ }_{t-1}$ & 7.47 & 2.02 & 48.69 & 36.57 \\
\hline No party identification $_{t-1}$ & 10.22 & 2.29 & 0.55 & 86.39 \\
\hline
\end{tabular}

Notes: SOEP, waves 1993-2009, rolling 1-year windows. Mainstream party identification is defined as being inclined towards one of the four major German parties, the Christian-Democrats (CDU/CSU), the Social Democrats (SPD), the Free Democratic Party (FDP) or the Greens (Alliance90/The Greens). The variable - No party identification - equals one if a person says that he/she does not feel close to any particular party. Extremist left-wing party is defined as feeling close to the party Die Linke, and extremist right-wing party affinity is defined as feeling close to one of three extremist right-wing parties in Germany.

The lower panel in Table 2 points to some differences in the persistence of party identification between West Germans and East Germans. Among East Germans, the persistence in mainstream 
party identification between any two years is 67 percent, nearly 10 percentage points lower than among West Germans, whereas the persistence in far left-wing and far right-wing party identification is higher (66 percent and 49 percent, respectively). In addition, with regard to inflow into far left-wing party identification, it is striking that a higher proportion of East Germans who reported either mainstream party identification, no party identification or far right-wing party identification in one year change to support the former socialist party, Die Linke, in the following year. For example, around 2 percent of individuals who reported having no party identification in one year report identifying with Die Linke in the next. The corresponding proportion for West Germans is 0.3 percent. Moreover, fewer East Germans who reported a party identification at the extreme of the political spectrum in the previous year report a mainstream party identification in year t. For instance, 7 percent of East Germans who reported an affinity with an extremist right wing-party in year $t-1$ support one of the mainstream parties in year $t$, compared to around 13 percent among West Germans.

Table 3 reports yearly transition matrices for individuals' job loss fears. The table shows that there are also considerable changes in people's job worries from one year to the next. The upper panel in Table 3, for example, shows that nearly 1 in 4 West German workers who were not concerned about their job security in the previous year are somewhat concerned in the following year, and around 10 percent of them express being very concerned. The table also points to some striking differences between East Germans and West Germans. For instance, a considerably higher proportion of East German workers are somewhat concerned (62 percent) or very concerned (48 percent) about their own job security in any two successive survey years. The corresponding figures for West Germans are 57 percent and 41 percent, respectively.

In sum, the transition matrices suggest that there is considerable change in individuals' party identification and job loss fears over time such that we can hope to identify the role of job loss 
Table 3: Transitions in Job Loss Fears

\begin{tabular}{|c|c|c|c|}
\hline Worries about own job security & $\begin{array}{c}\text { Not } \\
\text { concerned }_{t}\end{array}$ & $\begin{array}{l}\text { Somewhat } \\
\text { concerned }_{t}\end{array}$ & $\begin{array}{c}\text { Very } \\
\text { concerned }_{t}\end{array}$ \\
\hline \multicolumn{4}{|l|}{ West Germans } \\
\hline Not concerned $_{t-1}$ & 65.65 & 23.80 & 10.39 \\
\hline Somewhat concerned $_{t-1}$ & 23.46 & 57.01 & 37.46 \\
\hline Very concerned $_{t-1}$ & 3.02 & 12.44 & 40.71 \\
\hline \multicolumn{4}{|l|}{ East Germans } \\
\hline Not concerned $_{t-1}$ & 56.91 & 15.61 & 4.71 \\
\hline Somewhat concerned $_{t-1}$ & 32.01 & 62.07 & 30.70 \\
\hline Very concerned $_{t-1}$ & 3.77 & 14.57 & 47.75 \\
\hline
\end{tabular}

Notes: SOEP, waves 1993-2009, rolling 1-year windows. Only employees.

fears for party identification in an econometric model controlling for various explanatory variables and unobserved time-invariant individual effects.

\section{$5 \quad$ Panel Estimations and Results}

To account for the categorical nature of party identification we estimate multinomial logit panel models with mainstream party identification constituting the baseline category $(k=0)$. The probability of individual $i$ identifying with any other party $k=1, . ., J$ at time $t$ is assumed to follow a logistic distribution:

$$
\operatorname{Pr}\left(y_{i t}=k\right)=\frac{\exp \left(X_{i t} \beta_{k}+\alpha_{i}\right)}{1+\sum_{k=1}^{J} \exp \left(X_{i t} \beta_{k}+\alpha_{i}\right)}
$$

with $X_{i t}$ denoting the set of control variables: age (three groups: Age $\leq 27$, Age 28-45, Age $\geq 46$ ), a dummy for male gender (D: male), marital status (D: married), Number of children, a dummy for high to medium education ( $D$ : high to medium skilled) corresponding to more than general elementary schooling following the International Standard Classification of Education (OECD, 1999), a dummy for tertiary education of father and mother (D: Mother, Father high skilled), item non-response dummies for maternal and paternal education (not reported), post government 
household income ( $\log \mathrm{HH}$-income), the share of labor income in total household income (HHshare of labor income), a dummy for being unemployed (D: unemployed), and a dummy for being out of the labor force (D: out of labor force), that is for having no job while not actively looking for work. In addition, a full set of survey year dummy variables (not reported in the tables) is included. Most importantly, we capture job loss fears with two mutually exclusive dummy variables. The first takes on the value one if individuals are very concerned about their job security, and zero otherwise (D: very concerned about job security). The second dummy variable equals to one if individuals are somewhat concerned, and zero otherwise (D: somewhat concerned about job security). Naturally, job loss fears are only defined for respondents who are employed at the time of the interview. Accordingly, the two dummy variables for job loss fears are interacted with an indicator variable for being employed ( $D$ : employed). Hence, the coefficients on the labor force status variables and job loss fears need to be interpreted with respect to the baseline category of being employed without job loss fears. To allow for potential heterogeneity in political socialization, we estimate separate models for West and East Germans. Descriptive statistics for the control variables used are reported in Table 4. 
Table 4: Descriptive Statistics

\begin{tabular}{|c|c|c|c|c|}
\hline & \multicolumn{2}{|c|}{ West Germans } & \multicolumn{2}{|c|}{ East Germans } \\
\hline & Mean & $\begin{array}{l}\text { Standard } \\
\text { Deviation }\end{array}$ & Mean & $\begin{array}{l}\text { Standard } \\
\text { Deviation }\end{array}$ \\
\hline Age $28-45$ & 0.50 & 0.50 & 0.45 & 0.50 \\
\hline Age $\geq 46$ & 0.30 & 0.46 & 0.33 & 0.47 \\
\hline D: Married & 0.61 & 0.49 & 0.58 & 0.49 \\
\hline Number of children & 0.76 & 1.02 & 0.62 & 0.85 \\
\hline D: Male & 0.47 & 0.50 & 0.47 & 0.50 \\
\hline D: high to medium skilled & 0.82 & 0.38 & 0.89 & 0.31 \\
\hline D: Mother high skilled & 0.05 & 0.22 & 0.06 & 0.24 \\
\hline D: Father high skilled & 0.10 & 0.31 & 0.10 & 0.30 \\
\hline Log HH-income & 10.58 & 0.75 & 10.26 & 0.84 \\
\hline HH Share of labor income & 95.86 & 10.35 & 97.20 & 8.07 \\
\hline D: unemployed & 0.04 & 0.20 & 0.11 & 0.31 \\
\hline D: out of labor force & 0.30 & 0.46 & 0.22 & 0.41 \\
\hline $\begin{array}{l}D: \text { employed } \times D: \text { very concerned } \\
\text { about job security } \\
D \cdot \text { emploued } \times D \cdot \text { somewhat concerned }\end{array}$ & 0.09 & 0.28 & 0.16 & 0.36 \\
\hline $\begin{array}{l}\text { D: employed } \times D \text { : somewhat concernea } \\
\text { about job security }\end{array}$ & 0.28 & 0.45 & 0.34 & 0.47 \\
\hline Observations & & 4,778 & & 50,806 \\
\hline
\end{tabular}

Notes: SOEP, waves 1993-2009. 
We control for unobserved individual heterogeneity $\alpha_{i}$ following Mundlak's approach (Mundlak, 1978), that is, we assume that unobserved individual heterogeneity can be projected by the individual-specific sample means of all the time-varying control variables. In addition, we include measures of parental education. A limitation of the Mundlack approach is that the individualspecific unobserved effect may be correlated with time-invariant explanatory variables, resulting in inefficient and biased estimates. As additional evidence, we report estimates from conditional logit models, which explicitly allow the unobserved individual effect to be correlated with the explanatory variables. By independently assessing the probabilities of identifying with extremist left-wing and right-wing parties, we are able to condition out any time-constant individual unobserved characteristics (see Chamberlain, 1980). ${ }^{13}$

Moreover, our estimation method does not account for unobserved shocks that affect both individuals' job loss fears and the political outcome variable of interest. If, for example, certain individuals experienced an unobserved event that is associated with their economic worries and their party attachment, then the present estimates would suffer from omitted variable bias. To minimize this risk, we control for a rich set of individual-, household- and family-specific explanatory variables. We also control for a maximum set of time dummy variables that should capture any changes in the economic environment, such as business cycle effects or changes in the political environment over time. Moreover, in unreported regressions, we also investigated the robustness of our estimates when also controlling for other subjective worries, such as general economic worries or worries about the environment.

Tables 5 and 6 report the estimated relative risks for West and East Germans utilizing a Mundlak specification of a standard multinomial panel logit model with mainstream party identification

\footnotetext{
${ }^{13}$ In order to compare our findings with the previous literature, we also estimated simple cross-sectional multinomial logit models ignoring unobserved heterogeneity $\alpha_{i}$. Results are available from the authors upon request.
} 
as the baseline category. Before looking at our key variables of interest, we briefly discuss the effects of explanatory variables that are strongly related to the political outcome measures, even after controlling for individual unobserved heterogeneity. The estimates in Tables 5 and 6 point to a significant relationship between the respondent's age, gender, parental education, household income and party identification. For example, consistent with previous work (Siedler, 2011), the relative risk of identifying with the far right is much larger for men than for women. For West Germans, the relative risk differs by about 97 percent, for East Germans the difference is as high as 280 percent. Moreover, we find parental education to significantly affect extremist right-wing and left-wing party identification, but in opposite ways. West Germans whose fathers or mothers have high educational attainment (university degree) have a 43 respectively 51 percent lower relative risk of identifying with the far right. For East Germans, we find only the mother's education to affect extremist right-wing party identification. At the same time, high educational attainment of the father is found to raise the relative risk of identifying with the extremist left by 36 percent for West Germans and by 53 percent for East Germans. Household income is found to significantly affect the relative risk of identifying with extremist right-wing and far left-wing parties, at least among East Germans. An one percent increase in household income lowers the relative risk of identifying with the extremist right or left by about 24 percent. For West Germans, the effect is not identified with sufficient precision after controlling for unobserved heterogeneity. ${ }^{14}$

Regarding our key variables of interest, for West Germans, the estimates in Table 5 indicate that the effect of job loss fears on extremist left-wing party identification is positive but cannot be estimated with sufficient precision. However, with respect to right-wing extremism, we find a sizable and statistically significant effect. Being "very concerned" about job security raises the

\footnotetext{
${ }^{14} \mathrm{~A}$ simple multinomial logit model ignoring unobserved heterogeneity, however, confirms the close association between income and extremist party identification for West Germans as well.
} 
Table 5: Mundlak Specification of Multinomial Logit Model, West Germans

\begin{tabular}{|c|c|c|c|}
\hline & $\begin{array}{c}\text { Extremist left-wing } \\
\text { party }\end{array}$ & $\begin{array}{c}\text { Extremist right-wing } \\
\text { party }\end{array}$ & $\begin{array}{c}\text { No party } \\
\text { identification }\end{array}$ \\
\hline \multirow[t]{2}{*}{ Age $28-45$} & $0.622^{*}$ & 0.919 & $0.840^{* * *}$ \\
\hline & $(0.156)$ & $(0.164)$ & $(0.030)$ \\
\hline \multirow[t]{2}{*}{ Age $\geq 46$} & 1.434 & 0.717 & $0.877 * * *$ \\
\hline & $(0.477)$ & $(0.210)$ & $(0.042)$ \\
\hline \multirow[t]{2}{*}{ D: Married } & $0.601^{* *}$ & 0.946 & $0.917^{* * *}$ \\
\hline & $(0.138)$ & $(0.177)$ & $(0.030)$ \\
\hline \multirow[t]{2}{*}{ Number of children } & 0.964 & 1.073 & $0.974^{*}$ \\
\hline & $(0.097)$ & $(0.090)$ & $(0.014)$ \\
\hline \multirow[t]{2}{*}{ D: Male } & $1.276^{* *}$ & $1.974^{* * *}$ & $0.683^{* * *}$ \\
\hline & $(0.124)$ & $(0.180)$ & $(0.010)$ \\
\hline \multirow[t]{2}{*}{ D: high to medium skilled } & 0.737 & 1.018 & $0.741^{* * *}$ \\
\hline & $(0.203)$ & $(0.201)$ & $(0.028)$ \\
\hline \multirow[t]{2}{*}{ D: Mother high skilled } & 0.999 & $0.515^{* *}$ & $0.703^{* * *}$ \\
\hline & $(0.194)$ & $(0.142)$ & $(0.023)$ \\
\hline \multirow[t]{2}{*}{ D: Father high skilled } & $1.363^{* *}$ & $0.433^{* * *}$ & $0.736^{* * *}$ \\
\hline & $(0.201)$ & $(0.089)$ & $(0.017)$ \\
\hline \multirow[t]{2}{*}{ Log HH-income } & 1.017 & 1.027 & 0.978 \\
\hline & $(0.099)$ & $(0.088)$ & $(0.016)$ \\
\hline \multirow{2}{*}{ HH-share of labor income } & 1.009 & 1.004 & 1.001 \\
\hline & $(0.007)$ & $(0.006)$ & $(0.001)$ \\
\hline \multirow[t]{2}{*}{ D: unemployed } & 1.151 & 0.888 & 0.960 \\
\hline & $(0.309)$ & $(0.208)$ & $(0.042)$ \\
\hline \multirow[t]{2}{*}{ D: out of labor force } & 1.334 & $1.450 * *$ & $1.047^{*}$ \\
\hline & $(0.270)$ & $(0.245)$ & $(0.029)$ \\
\hline \multicolumn{4}{|c|}{$D:$ employed $\times D:$ very concerned } \\
\hline \multirow[t]{2}{*}{ about job security } & 1.219 & $1.406^{* *}$ & 1.013 \\
\hline & $(0.252)$ & $(0.244)$ & $(0.033)$ \\
\hline \multicolumn{4}{|c|}{$D:$ employed $\times D:$ somewhat concerned } \\
\hline \multirow[t]{2}{*}{ about job security } & 1.068 & 1.079 & 1.005 \\
\hline & $(0.167)$ & $(0.142)$ & $(0.022)$ \\
\hline \multirow[t]{2}{*}{ Constant } & $0.083^{* *}$ & $5.026^{*}$ & $10.62^{* * *}$ \\
\hline & $(0.089)$ & $(4.787)$ & $(1.696)$ \\
\hline Observations & 104,778 & 104,778 & 104,778 \\
\hline Log-likelihood & -74020 & -74020 & -74020 \\
\hline
\end{tabular}

Notes: SOEP, waves 1993-2009. Odds ratios of coefficients. Standard errors in parentheses. **, ${ }^{* *},{ }^{* * *}$ Statistically significant at the 10-percent, the 5-percent, the 1-percent level. Full set of year dummies included. Item non-response dummies included. 
relative risk of affinity to an extremist right-wing party by 41 percent. Furthermore, job loss fears do not affect the risk of having no party identification. For East Germans the impact of job loss fears is even larger. As shown in Table 6, being "very concerned" about job security raises the relative risk of identifying with the extremist right as opposed to mainstream parties by 90 percent, whereas being "somewhat concerned" about job security results in a respective relative risk increase of 57 percent.

Reflecting on Falter (1983) who argues that in the Weimar Republic it was mainly those Germans who feared the loss of their economic status that supported the Nazis, rather than the actually unemployed we want to access the effects of job loss fears on extremist party identification in relation to labor force status in our modern context. First, as reported in Table 5, among West Germans we find no statistically significant impact of unemployment on party identification, but, respondents who report being out of the labor force - (i.e., those who have no job and are not actively looking for work) - are 45 percent more likely to identify with extremist right-wing parties than employed respondents who report no concerns about job security. Accordingly, for respondents who are not actively looking for work and for respondent who do work but are very concerned about their job security we find a similar risk of identifying with extremist right-wing parties.

In contrast, for extremist left-wing party identification, however, our estimates suggest that labor force status does not play an important role. Similarly, regarding the risk of withdrawing support for political parties altogether, we find only very small effects of labor force status, which are weakly statistically significant for respondent who are out of the labor force.

For East Germans, the effect of not having a job is more pronounced. Being unemployed or out of the labor force raises the relative risk of identifying with extremist right-wing parties by 113 respectively 82 percent compared to employees who do not report concerns about job security. 
Table 6: Mundlak Specification of Multinomial Logit Model, East Germans

\begin{tabular}{|c|c|c|c|}
\hline & $\begin{array}{c}\text { Extremist left-wing } \\
\text { party }\end{array}$ & $\begin{array}{c}\text { Extremist right-wing } \\
\text { party }\end{array}$ & $\begin{array}{c}\text { No party } \\
\text { identification }\end{array}$ \\
\hline Age $28-45$ & $\begin{array}{c}0.577^{* * *} \\
(0.069)\end{array}$ & $\begin{array}{c}0.934 \\
(0.187)\end{array}$ & $\begin{array}{c}0.842^{* * *} \\
(0.051)\end{array}$ \\
\hline Age $\geq 46$ & $\begin{array}{c}0.518^{* * *} \\
(0.081)\end{array}$ & $\begin{array}{c}0.780 \\
(0.248)\end{array}$ & $\begin{array}{c}0.918 \\
(0.074)\end{array}$ \\
\hline D: Married & $\begin{array}{c}0.840 \\
(0.095)\end{array}$ & $\begin{array}{c}0.555^{* * *} \\
(0.125)\end{array}$ & $\begin{array}{l}0.895^{*} \\
(0.053)\end{array}$ \\
\hline Number of children & $\begin{array}{l}0.917^{*} \\
(0.046)\end{array}$ & $\begin{array}{l}1.223^{* *} \\
(0.116)\end{array}$ & $\begin{array}{c}1.020 \\
(0.026)\end{array}$ \\
\hline D: Male & $\begin{array}{c}0.967 \\
(0.041)\end{array}$ & $\begin{array}{c}3.808^{* * *} \\
(0.420)\end{array}$ & $\begin{array}{c}0.753^{* * *} \\
(0.017)\end{array}$ \\
\hline D: high to medium skilled & $\begin{array}{c}0.824 \\
(0.110)\end{array}$ & $\begin{array}{c}0.565^{* * *} \\
(0.121)\end{array}$ & $\begin{array}{c}0.668^{* * *} * \\
(0.045)\end{array}$ \\
\hline D: Mother high skilled & $\begin{array}{c}0.979 \\
(0.083)\end{array}$ & $\begin{array}{c}0.604^{* *} \\
(0.118)\end{array}$ & $\begin{array}{c}0.849 * * * \\
(0.041)\end{array}$ \\
\hline D: Father high skilled & $\begin{array}{c}1.525^{* * *} \\
(0.101)\end{array}$ & $\begin{array}{c}0.987 \\
(0.153)\end{array}$ & $\begin{array}{c}0.709^{* * *} \\
(0.028)\end{array}$ \\
\hline Log HH-income & $\begin{array}{c}0.869 * * * \\
(0.037)\end{array}$ & $\begin{array}{l}0.859^{*} \\
(0.070)\end{array}$ & $\begin{array}{l}0.952^{*} \\
(0.024)\end{array}$ \\
\hline HH-share of labor income & $\begin{array}{c}1.000 \\
(0.003)\end{array}$ & $\begin{array}{c}1.000 \\
(0.006)\end{array}$ & $\begin{array}{l}1.004^{* *} \\
(0.002)\end{array}$ \\
\hline D: unemployed & $\begin{array}{c}1.101 \\
(0.120)\end{array}$ & $\begin{array}{c}2.131^{* * *} \\
(0.466)\end{array}$ & $\begin{array}{c}1.021 \\
(0.059)\end{array}$ \\
\hline D: out of labor force & $\begin{array}{c}1.145 \\
(0.115)\end{array}$ & $\begin{array}{c}1.824^{* * *} \\
(0.397)\end{array}$ & $\begin{array}{c}1.059 \\
(0.056)\end{array}$ \\
\hline $\begin{array}{l}D: \text { employed } \times D: \text { very concerned } \\
\text { about job security }\end{array}$ & $\begin{array}{c}0.975 \\
(0.093)\end{array}$ & $\begin{array}{c}1.901^{* * *} \\
(0.390)\end{array}$ & $\begin{array}{c}0.998 \\
(0.049)\end{array}$ \\
\hline $\begin{array}{l}D: \text { employed } \times D: \text { somewhat concerned } \\
\text { about job security }\end{array}$ & $\begin{array}{c}0.948 \\
(0.072)\end{array}$ & $\begin{array}{l}1.566^{* *} \\
(0.274)\end{array}$ & $\begin{array}{c}1.049 \\
(0.040)\end{array}$ \\
\hline Constant & $\begin{array}{l}1.455 \\
(0.779)\end{array}$ & $\begin{array}{c}2.216 \\
(2.576)\end{array}$ & $\begin{array}{c}24.37^{* * *} \\
(7.361)\end{array}$ \\
\hline $\begin{array}{l}\text { Observations } \\
\text { Log-likelihood }\end{array}$ & $\begin{array}{l}50,806 \\
-38612\end{array}$ & $\begin{array}{l}50,806 \\
-38612\end{array}$ & $\begin{array}{l}50,806 \\
-38612\end{array}$ \\
\hline
\end{tabular}

Notes: SOEP, waves 1993-2009. Odds ratios of coefficients. Standard errors in parentheses. *, ${ }^{* *},{ }^{* * *}$ Statistically significant at the 10-percent, the 5-percent, the 1-percent level. Full set of year dummies included. Item non-response dummies included. 
Compared to the role of objective labor force status, subjective job loss fears thus have a slightly smaller impact on extremist right-wing party identification but clearly still are very sizable.

Whereas the Mundlak approach presented above rests on the assumption that unobserved heterogeneity essentially can be captured by the control variables' individual-specific sample means, Table 7 depicts the odds ratios from independent conditional logit estimations. In line with the results in Tables 5 and 6 , we find job loss fears to have no significant effect on left-wing extremism or withdrawal of overall party identification. Furthermore, we again find extremist right-wing party identification to be positively affected by job loss fears. West Germans who report being very concerned about their job security face a 58 percent higher relative risk of identifying with extremist right-wing parties. East Germans who report being somewhat or very concerned about their job security have a corresponding relative risk increase of 70 percent or 100 percent, respectively. Accordingly, our conditional logit estimates have the same direction and similar magnitude as the ones from the Mundlak specification of the multinomial logit model. Similarly, the effect of having no job, that is of being unemployed or out of the labor force, is comparable in direction and magnitude between both model specifications.

Summarizing, the most important pattern that emerges from Tables 5 to 7 is that for West and East Germans alike, albeit to different degrees, perceived job insecurities prompt workers to support far right-wing parties. This result is robust to controlling for non-random unobserved personality traits and other time-constant individual characteristics. Being out of the labor force is also an important predictor of extremist right-wing party identification, but current unemployment has only a positive and statistically significant effect on far right-wing party affinity in East Germany. Overall, the panel estimates are consistent with the relative deprivation theory (Kleinert et al., 1998; Falk et al., 2011), which suggests that unemployment or the fear of losing one's job might cause a decline in social status and intensify anti-foreign sentiments and far right-wing attitudes. 
A larger impact of job loss fears and subjective unemployment on East German respondents' far right-wing party affinities might be explained by differences in social norms or by the fact that the stability of affinities with mainstream parties is considerably lower among East Germans than among West Germans (see Table 2). Alternatively, this result might be driven partly by the higher prevalence and strength of far right-wing parties at the regional level in East than in West Germany. 
Table 7: Conditional Logit Model, West and East Germans

\begin{tabular}{|c|c|c|c|}
\hline & $\begin{array}{l}\text { Extremist left-wing } \\
\text { party }\end{array}$ & $\begin{array}{l}\text { Extremist right-wing } \\
\text { party }\end{array}$ & $\begin{array}{c}\text { No party } \\
\text { identification }\end{array}$ \\
\hline \multicolumn{4}{|l|}{ Panel A: West Germans } \\
\hline D: unemployed & $\begin{array}{c}1.223 \\
(0.444)\end{array}$ & $\begin{array}{c}0.909 \\
(0.274)\end{array}$ & $\begin{array}{c}0.978 \\
(0.058)\end{array}$ \\
\hline D: out of labor force & $\begin{array}{c}1.155 \\
(0.356)\end{array}$ & $\begin{array}{c}1.671^{* * *} \\
(0.403)\end{array}$ & $\begin{array}{l}1.073^{*} \\
(0.041)\end{array}$ \\
\hline $\begin{array}{l}D: \text { employed } \times D: \text { very concerned } \\
\text { about job }+ \text { security }\end{array}$ & $\begin{array}{l}1.448 \\
(0.416)\end{array}$ & $\begin{array}{l}1.581^{* *} \\
(0.348)\end{array}$ & $\begin{array}{l}1.043 \\
(0.047)\end{array}$ \\
\hline $\begin{array}{l}D: \text { employed } \times D: \text { somewhat concerned } \\
\text { about job security }\end{array}$ & $\begin{array}{l}1.057 \\
(0.236)\end{array}$ & $\begin{array}{c}1.164 \\
(0.206)\end{array}$ & $\begin{array}{c}1.021 \\
(0.031)\end{array}$ \\
\hline $\begin{array}{l}\text { Observations } \\
\text { Log-likelihood }\end{array}$ & $\begin{array}{l}2,158 \\
-514.7\end{array}$ & $\begin{array}{r}2,450 \\
-741.1\end{array}$ & $\begin{array}{l}61,895 \\
-24296\end{array}$ \\
\hline \multicolumn{4}{|l|}{ Panel B: East Germans } \\
\hline D: unemployed & $\begin{array}{c}1.190 \\
(0.185)\end{array}$ & $\begin{array}{c}2.767 \text { *** } \\
(0.786)\end{array}$ & $\begin{array}{c}0.981 \\
(0.070)\end{array}$ \\
\hline D: out of labor force & $\begin{array}{l}1.120 \\
(0.160)\end{array}$ & $\begin{array}{c}2.183^{* * *} \\
(0.615)\end{array}$ & $\begin{array}{l}1.064 \\
(0.069)\end{array}$ \\
\hline $\begin{array}{l}D: \text { employed } \times D: \text { very concerned } \\
\text { about job security }\end{array}$ & $\begin{array}{c}0.919 \\
(0.125)\end{array}$ & $\begin{array}{c}2.050^{* * *} \\
(0.541)\end{array}$ & $\begin{array}{l}1.005 \\
(0.062)\end{array}$ \\
\hline $\begin{array}{l}D: \text { employed } \times D: \text { somewhat concerned } \\
\text { about job security }\end{array}$ & $\begin{array}{c}0.868 \\
(0.097)\end{array}$ & $\begin{array}{l}1.704^{* *} \\
(0.388)\end{array}$ & $\begin{array}{l}1.076 \\
(0.052)\end{array}$ \\
\hline Observations & 7,290 & 2,025 & 28,711 \\
\hline Log-likelihood & -2424 & -606.9 & -10989 \\
\hline
\end{tabular}

Notes: SOEP, waves 1993-2009. Odds ratios of coefficients. Standard errors in parentheses. The models include all time changing control variables from Tables 5 and $6 .^{*},{ }^{* *}, * * *$ Statistically significant at the 10 -percent, the 5 -percent, the 1-percent level. 


\section{Conclusion}

This study provides new evidence regarding the effect of job loss fears on political party identification. Our panel estimates suggest that increases in individuals' perceived job insecurities significantly raise their risk of supporting extremist right-wing parties. West Germans who report being very concerned about their job security have a 41 percent higher relative risk of expressing an affinity to an extremist right-wing party than those who report no job loss fears. The panel estimates for the East German sample point to slightly stronger effects: East Germans who report being very (somewhat) concerned about job loss have a 90 (57) percent higher relative risk of affinity to an extremist right-wing party than employed East Germans without job loss fears. Another import determinant of extremist right-wing party identification is objective labor force status. Being out of the labor force and to a lesser degree being unemployed significantly increases the risk of supporting extremist right-wing parties. However, in terms of political outcomes subjective job loss fears probably matter more as by far most Germans are actually employed and potentially worry about their job security.

Our findings on the importance of subjective fears has an interesting parallel in history: recent studies on the elections in the Weimar Republic have presented evidence that it was mainly those who feared a loss of work or economic status who supported the Nazi party. Our results indicate that subjective job loss fears matter today as well.

Of course, Germany's modern democracy is not comparable to the Weimar Republic of the 1930s and there is no reason for alarmism regarding the overall stability of its democratic institutions. However, our finding that perceptions of economic insecurity are indeed an important factor in the success of the extremist right may be seen as particularly relevant against the backdrop of recent electoral successes of far right-wing parties across Europe. In future research, it would 
be interesting to examine whether perceived job insecurities have similar consequences in other countries and whether this has yet resulted in stronger anti-capitalist and anti-globalist policy initiatives.

\section{References}

Abramson, P. R., "Generational Change and the Decline of Party Identification in America: 1952-1974," American Political Science Review, 1976, 70 (2), 469-478.

Alesina, A. and N. Fuchs-Schündeln, "The Effect of Communism on People's Preferences," American Economic Review, 2007, 97 (4), 1507-1528.

and P. Giuliano, "Family Ties and Political Participation," Journal of the European Economic Association, forthcoming.

Anderson, C. J., "Economic Voting and Political Context: A Comparative Perspective," Electoral Studies, 2000, 19, 151-170.

Arzheimer, K., Die Wähler der extremen Rechten 1980-2002, Wiesbaden: VS Verlag fr Sozialwissenschaften, 2008.

Bartle, J., "Partisanship, Performance and Personality: Competing and Complementary Characterizations of the 2010 British General Election," Party Politics, 2003, 9 (3), 317-345.

Blanchflower, D. G., "Fear, Unemployment and Pay Flexibility," Economic Journal, 1991, 101 (406), 483-496.

Brunner, E., S. L. Ross, and E. Washington, "Economics and Policy Preferences: Causal Evidence of the Impact of Economic Conditions on Support for Redistribution and Other Ballot Proposals," Review of Economics and Statistics, 2011, 93 (3), 888-906. 
Brynin, M. and D. Sanders, "Party Identification, Political Preferences and Marital Conditions: Evidence from the British Household Panel Survey, 1991-2," Party Politics, 1993, 3, 53-77.

Bundeswahlleiter, Online available at http://www.bundeswahlleiter.de, 2010.

Campbell, A., P. E. Converse, W. E. Miller, and D. E. Stokes, The American Voter, Midway Reprint. Chicago: Chicago University Press, 1960.

Campbell, D., A. Carruth, A. Dickerson, and F. Green, "Job Insecurity and Wages," Economic Journal, 2007, 117 (March), 544-566.

Chamberlain, G., "Analysis of covariance with qualitative data," Review of Economic Studies, 1980, 47, 225-238.

Cohen, J. and J. Agiesta, "Lots of Fear Remains over Economy, Job Losses," Washington Post, 2009, September 15.

Corneo, G., "Nationalism, Cognitive Ability, and Interpersonal Relations," International Review of Economics, 2010, 57 (2), 119-141.

and O. Jeanne, "A Theory of Tolerance," Journal of Public Economics, 2009, 93 (5-6), $691-702$.

Dalton, R. J., "The Decline of Party Identifications," in R. J. Dalton and M. P. Wattenberg, eds., Parties without Partisans, Oxford University Press, Oxford 2002, pp. 19-36.

Die Linke, "Programme of DIE LINKE Party, First Draft," http://dielinke.de/programm/programmentwurf/, 2010.

Downs, A., An Economic Theory of Democracy, New York: Harper Row, 1957. 
Edlund, L. and R. Pande, "Why Have Women Become Left-Wing? The Political Gender Gap and the Decline in Marriage," Quarterly Journal of Economics, 2002, 117 (3), 917-961.

Falk, A., A. Kuhn, and J. Zweimüller, "Unemployment and Right-Wing Extremist Crime," Scandinavian Journal of Economics, 2011, 113 (2), 260-285.

Falter, W. J., "Arbeitslosigkeit und Nationalsozialismus. Eine empirische Analyse des Beitrags der Massenarbeitslosigkeit zu den Wahlerfolgen der NSDAP 1932 und 1933," Kölner Zeitschrift für Soziologie und Sozialpsychologie, 1983, 3, 525-554.

, Wer wählt rechts?, München: C. H. Beck, 1994.

Fiorina, M. P., Retrospective Voting in American National Elections, New Haven, CT: Yale University Press, 1981.

Haisken-DeNew, J. and J. R. Frick, Desktop Companion to the German Socio-Economic Panel (SOEP) - Version 8.0, DIW Berlin, 2005.

King, G., O. Rosen, M. Tanner, and A. F. Wagner, "Ordinary Economic Voting Behavior in the Extraordinary Election of Adolf Hitler," Journal of Economic History, 2008, 68 (4), 951-996.

Kleinert, C., W. Krüger, and H. Willems, "Einstellungen junger Deutscher gegenüber ausländischen Mitbürgern und ihre Bedeutung hinsichtlich politischer Orientierungen," Aus Politik und Zeitgeschichte, 1998, 31, 14-27.

Kroh, M. and P. Selb, "Individual and Contextual Origins of Durable Partisanship," in J. Bartle and P. Bellucci, eds., Political Parties and Particanship: Social Identity and Individual Attitudes, Routledge, London 2009, pp. 107-120. 
and ___ "Inheritance and the Dynamics of Party Identification," Political Behavior, 2009, $31,559-574$.

Lewis-Beck, M. S., "Comparative Economic Voting: Britain, France, Germany, Italy," American Journal of Political Science, 1986, 30, 315-346.

, Economics and Elections, Ann Arbor: University of Michigan Press, 1988.

and M. Stegmaier, "Economic Determinants of Electoral Outcomes," Annual Review of Political Science, 2000, 3, 183-219.

Lubbers, M. and P. Scheepers, "Individual and Contextual Characteristics of the German Extreme Right-Wing Vote in the 1990s. A Test of Complementary Theories," European Journal of Political Research, 2000, 38 (1), 63-94.

Malhotra, N. and J. A. Krosnick, "Retrospective and Prospective Performance Assessments during the 2004 Election Campaign: Tests of Mediation and News Media Priming," Political Behavior, 2007, 29, 249-278.

Meyer-Timpe, U., "Der Wert der Arbeit," DIE ZEIT. Online available at http://www.zeit.de/zeit-wissen/2010/04/Dossier-Jobverlust-Arbeit, 2010.

Mundlak, Y., "On the Pooling of Time Series and Cross Section Data," Econometrica, 1978, 46 (1), 69-85.

Neu, V., Das Janusgesicht der PDS - Wähler und Partei zwischen Demokratie und Extremismus, NOMOS Verlagsgesellschaft: Baden-Baden, 2004.

New York Times, "Neo-Nazis Suspected in Long Wave of Crimes, Including Murders, in Germany," 14 November 2011. 
Nolan, J. P., I. C. Wichert, and B. J. Burchell, "Job Insecurity, Psychological Well-Being and Family Life," in E. Heery and J. Salmon, eds., The Insecure Workforce, Routledge, London and New York 2000, pp. 181-209.

OECD, Classifying Educational Programmes: Manual for ISCED-97 Implementation in OECD Countries, Paris: OECD, 1999.

Oesch, D., "Explaining Workers' Support for Right-Wing Populist Parties in Western Europe: Evidence from Austria, Belgium, France, Norway, and Switzerland," International Political Science Review, 2008, 29 (3), 349-373.

Oswald, A. J. and N. Powdthavee, "Daughters and Left-Wing Voting," Review of Economics and Statistics, 2010, 92 (2), 213-227.

Powell, G. B. and G. D. Whitten, "A Cross-National Analysis of Economic Voting: Taking Account of the Political Context," American Journal of Political Science, 1993, 37, 391-414.

Rainer, H. and T. Siedler, "Does Democracy foster Trust?," Journal of Comparative Economics, 2009, 37 (2), 251-269.

Rätzel, S. and A. Knabe, "Scarring or scaring? The Psychological Impact of Past Unemployment and Future Unemployment Risk," Economica, 2009, 78 (310), 283-293.

Schneider, F., "Public Attitudes towards Economic Conditions and their Impact on Government Behavior," Poltical Behavior, 1984, 6 (3), 211-227.

Sheafer, T., "The Media and Economic Voting in Israel," International Journal of Public Opinion Research, 2008, 20 (1), 33-51. 
Siedler, T., "Schooling and Citizenship in a Young Democracy: Evidence from Postwar Germany," Scandinavian Journal of Economics, 2010, 112 (2), 315-338.

_ _ , "Parental Unemployment and Young People's Extreme Right-Wing Party Affinity: Evidence from Panel Data," Journal of the Royal Statistical Society: Series A, 2011, 174 (3), 737-758.

Stephens, M., "Job Loss Expectations, Realizations, and Household Consumption Behavior," Review of Economics and Statistics, 2004, 86 (1), 253-269.

Wagner, G. G., J. R. Frick, and J. Schupp, "The German Socio-Economic Panel Study (SOEP) - Scope, Evolution and Enhancements," Schmollers Jahrbuch, 2007, 127 (1), 139169.

Weatherford, M. S., "Economic Conditions and Electoral Outcomes: Class Differences in the Political Response to Recession," American Journal of Political Science, 1978, 22 (4), 917938.

Weisberg, H. F. and C. E. Smith, "The Influence of the Economy on Party Identification in the Reagan Years," Journal of Politics, 1991, 53 (4), 1077-1092.

Westle, B. and O. Niedermayer, "Contemporary Right-Wing Extremism in West Germany," European Journal of Political Research, 1992, 22 (1), 83-100.

Zuckerman, A. S., J. Dasovic, and J. Fitzgerald, Partisan Families: The Social Logic of Bounded Partisanship in Germany and Britain, Cambridge: Cambridge University Press, 2007. 